\title{
A NEW STAND \\ OF HIERACIUM PILOSUM SCHLEICH. EX FROELICH (ASTERACEAE) IN THE POLISH TATRA MOUNTAINS
}

\author{
JERZY KRUK \\ Department of Plant Physiology and Biochemistry, \\ Faculty of Biochemistry, Biophysics and Biotechnology, Jagiellonian University \\ Gronostajowa 7, 30-387 Kraków, Poland \\ e-mail: jerzy.kruk@uj.edu.pl
}

(Received: February 19, 2010. Accepted: March 4, 2010)

\begin{abstract}
A new stand of $H$. pilosum, a species not reported before from the territory of Poland, was found in the Polish Western Tatra Mts. It grows in numerous stands on limestone rocks on the slopes of Upłaziańska Kopka, at ca. $1400 \mathrm{~m}$ a.s.l. Moreover, typical form of this species, collected in the Polish Western Tatra Mts, was also found in herbaria of KRA and KRAM. These data indicate that H. pilosum is a widespread species in the described region but it was unrecognized from $H$. villosum so far.
\end{abstract}

KEY WORDS: Hieracium pilosum, Asteraceae, distribution, Western Tatra Mts, Poland.

\section{INTRODUCTION}

Hieracium pilosum Schleich. ex Froelich (H. morisianum Rchb. f., $H$. villosiceps Naegeli et Peter) occurs in the subalpine belt of mountains of Europe with central distribution in Alps (Aeschimann et al. 2004). The species grows preferentially on limestone rocks and soils in an association Seslerio-Caricetum sempervirentis. It shows a similar distribution, habitat and morphology to $H$. villosum.

As compared to $H$. villosum, ground leaves of $H$. pilosum are often more numerous and outer leaves of rosettes more rounded. $H$. pilosum shows lower number of cauline leaves - 3-6 vs (3-) 4-8 (-15) for $H$. villosum and the hairiness of the whole plant is more villous than in the case of $H$. villosum. The most pronounced trait differentiating both species is the shape and the arrangement of the involucral bracts. For $H$. pilosum all the bracts are of similar size and shape, narrow-lanceolate and adhering (Fig. 1). In the case of $H$. villosum the 3-8 outer bracts (the uppermost cauline leaves) are leaf-shaped, broad lanceolate, erect, causing the heads to be not so distinctly separated from the stem.

$H$. pilosum is known in the Western Carpathians only from the Slovakian part of the mountains. The first finding, given by Zahn (1930-1939), was from Mt Rozsutec in the Malá Fatra Mts. Further records from Malá Fatra (Krivánska Fatra) Mts were given (Suchý 1468 m, Stoh 1607 m), as well as from Velká Fatra Mts (Suchý vrch 1550 m, Čierny kameň 1480 m, Malá Pustalovčia 1559 m) by Bernátová et al. (1995). Recently, this species was found in the Western
Tatra Mts at the pass under Mt Osobitá, ca 1570 m (Chrtek et al. 2004). However, this species was not reported yet from the territory of the Polish Carpathians.

The four stands of $H$. pilosum in Velka Fatra were characterized as follows: 1) Seslerio variae-Caricetum tatrorum with a significant contribution of Astragalus penduliflorus; 2) phytocenosis with the dominance of Salix alpina; 3) Seslerio-Festucetum tatrae; 4) phytocenosis with the predominance of Carex ruprestis (Bernátová et al. 1995).

The chromosome number of $\mathrm{H}$. pilosum from Mt. Osobitá was $2 \mathrm{n}=27$ (Chrtek et al. 2004), i.e. the same as for $H$. villosum collected in Velká Fatra Mts, Malá Fatra Mts, Nízke Tatry Mts and Bielanske Tatry Mts (Chrtek et al. 2004). However, for $H$. villosum collected in other stands in the Western Carpathians, tetraploid chromosome number $(2 n=36)$ was recorded. Outside the Western Carpathians tetraploid counts also strongly prevail (Schuhwerk 1996).

\section{RESULTS}

A new stand of $H$. pilosum was found (12.07.2009) on Piec rocks, on the southern slopes of Upłaziańska Kopka, at an altitutde of ca $1400 \mathrm{~m}$ a.s.l., close to the tourist track leading to Ciemniak (Czerwone Wierchy) in the Western Tatra Mountains. The species grows in cleavages of limestone rocks exposed to the western direction, rarely solitary, usually in groups of dozens or more individuals. Alto- 


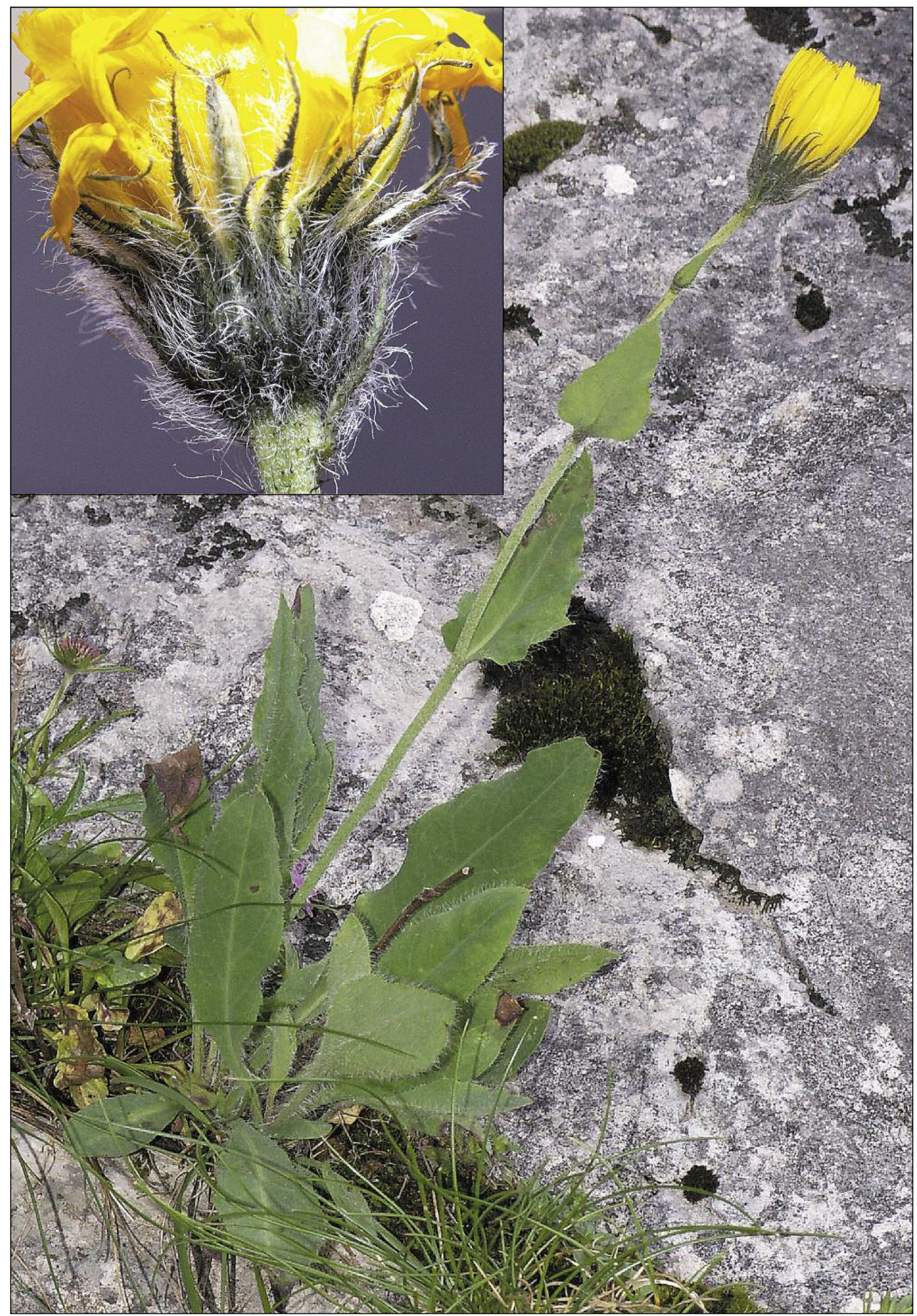

Fig. 1. Hieracium pilosum on Piec rocks in the Polish Western Tatra Mts (photo: J. Kruk, 12.07.2009).

[More photos of $H$. pilosum from the described stand taken by the author can be found at: http://www.atlas-roslin.pl] 
gether, around a few hundreds plants were found. It grows in nearly pure stands or in association with other plants, most often Carex firma.

As compared to the data from Velká Fatra Mts (Bernátová et al. 1995), where this species was a minor component of all the mentioned phytocenoses, the new stand of $H$. pilosum in the Polish Western Tatra Mts is considerably more abundant.

Typical $H$. pilosum was also found in herbaria of KRA and KRAM where it was collected in the Polish Western Tatra Mts (determined as H. villosum). Moreover, among the other investigated material, several specimens showed intermediate character between $H$. pilosum and $H$. villosum. These data indicate that $H$. pilosum is a widespread species in the Polish Western Tatra, but it was unrecognized from $H$. villosum so far.

Herbarium specimens of $H$. pilosum (ut $H$. villosum): lateral gully of Żleb Warzęcha at the foot of Mały Giewont, grassy terraces, 2.08.1912, leg. T. Wilczyński, det. J. Baryła (KRAM 264250-54); Giewont, swards in the mountain pass Wrótka, $1590 \mathrm{~m}, 7.08 .1973$, leg. A. Jasiewicz (KRAM 366137); Hala Królowa Wyżnia, Królowe Rówienki, swards at altitude $1550 \mathrm{~m}, 13.07 .1981$, leg. A. Jasiewicz (KRAM366138); Dol. ku Dziurze, limy rocks at outlet of cave, 1020 m, 5.07.1961, leg. R. Rajchel (KRA 0153343); Hala Tomanowa, bottom of a dried up brook, ca. 1340 m, 17.07.1961, leg. A. Pacyna (KRA0153344).
The specimen from the described stand was deposited in the herbarium of the Jagiellonian University (KRA).

\section{ACKNOWLEDGEMENTS}

The author is greatly indebted to Z. Szelag for the determination of the Hieracium specimen collected at the described stand and the fruitful discussion.

\section{LITERATURE CITED}

AESCHIMANN D., LAUBER K., MOSER D.M., THEURILLAT J.-P. 2004. Flora alpina. Haupt Verlag AG, Bern.

BERNÁTOVÁ D., KLIMENT J., OBUCH J., TOPERCER J. ml. (1995). K výskytu Hieracium pilosum v slovenskej časti Západných Karpát. Bull. Slov. Bot. Spoloč. 17: 72-74. (in Slovak)

CHRTEK J., MRÁZ P., SEVERA M. 2004. Chromosome numbers in selected species of Hieracium s. str. (Hieracium subgen. Hieracium) in the Western Carpathians. Preslia 76: 119-139 .

SCHUHWERK F. 1996. Published chromosome counts in Hieracium. URL [http:// www.botanischestaatssammlung.de/projects/chrzlit.html]

ZAHN K.H. 1930-1939. Hieracium. In: Graebner P. fil. (ed.), Synopsis der mitteleuropäischen Flora 12 (2-3) + Registerband, Leipzig. 